\title{
COMMERCIAL MANURES.
}

8
633
G64

$\triangle$ LECTURE DELIVERED BEFORE THE

FARMERS' CON VENTION

Held at Augusta, January, 1869,

$$
\text { - S. L. GOODALE, }
$$

BECRETAIY MAINE BOARD OF AGRYCULTUIE. 


$$
\text { 우 }
$$


. 





\section{COMMERCIAL MANURES.}

A LECTURE DELIVERED BEFORE THE

\section{FARMERS' CONVENTION}

HELD AT AUGUSTA, JANUARY, 1869,

$$
\text { B } \mathbf{X}
$$

S. L. GOODALE, SECRETART MAINE BOARD OF AGRICULTURE. 



\section{COMMERCIAL MANURES.}

The subject of commercial manures has been forcing itself upon the attention of the New England farmer for some years as one of steadily increasing importance. What has contributed to this more than any thing else, is the enhanced price of labor. In years gone by, when, with the help of his boys or with labor hired at $\$ 10$ or $\$ 12$ per month, and by using the manure of the farm-yard, he could get satisfactory crops, making both ends of the year meet, or perhaps finding a positive gain after the store bills and taxes were paid, in ready money or in betterments on the homestead, he gave little thought to the matter of far-fetched, artificial aids to fertilization.

But times have changed; values have changed; boys generally do not love the farm as well as they did when he was young. If he wants labor now, he must put up with a poor quality at a dear rate. It is evident that the conditions of success have changed, and that some new path must be found or he will be left astern. He now hears that concentrated manures may be bought; manures very unlike what he is accustomed to, but nevertheless able to bring good crops; and cheap enough to yield him handsome profits. He sees that, if this is true he can yet prosper by using more manure in proportion to the amount of labor than he did formerly; because sixty bushels of corn grown on one acre costs less than sixty bushels grown on two acres, by nearly the difference of half the labor bestowed on the two acres; and it is labor which he most needs to economise. He learns also that the price and the real value of these commercial manures do not uniformly correspond to each other; that some are high priced and yet very cheap, and that some are lower priced and yet quite dear, and some are dear at any price. Many are at a loss whether to buy or not. 
Previous to my acceptance of the position yet occupied as Secretary of this Board, I had given the subject of Commercial Manures only cursory thought; but the law defining the duties of the office, specified the investigation of such matters as pertained to the interests of agriculture; and there was no room for doubt, that among these the subject of manures held a very prominent position. Its chemistry was a pleasant task, for I well remember, when a lad, that my favorite play-room was the laboratory, and that more pocket money went for chemicals and apparatus than for jack-knives and skates.

Although I make no claim to having kept up with the rapid progress of chemical science during the intervening years, the endeavor has been made to keep within hailing distance, and on speaking terms.

Latterly, some thought has been given to the subject of manures in the way of business; and how that came to be I will relate.

Several years ago, being applied to by some of our leading farmers about where and how to obtain a satisfactory concentrated manure, the suggestion was offered that they make it for themselves; a company being formed, and power, machinery and all needful facilities being obtained, so as to work to advantage. The suggestion, although not immediately, was not long afterward adopted; and I have since served them as chemical director of the work. If an inferior article has ever been sent out by the Cumberland Bone Company, the blame is mine; for the only instructions ever given me were to make a very good article. I mention this business connection, in order that you may judge whether, and to what extent, partiality, or interest may find expression in the remarks submitted, and make allowance accordingly.

While no purpose is entertained to employ the present occasion to advertise the wares of one or another manufacturer, it may be permitted to say, that very soon following the establishment of the works alluded to, the commercial manures sold in competition with what was there made, rapidly improved in agricultural value-in 
one instance, several hundred per cent.-so that, whether the establishment was pecuniarily successful to those directly interested in it or not, the farming community has reaped immense bencfit.

Before speaking directly to the subject, it may be well to offor a few preliminary observations. And first, What do New England soils lack, which we need to buy?

Chemistry enables us to auswer this question with a good degree of certainty.

First, They lack Nitrogen in some combination from which plants can get it. Four-fifths of the atmosphere consists of nitrogen, but uircomlined; and in this state plants cannot appropriate it to their use. It may be supplied by nitrates, or by ammonia, or by any substances which yield ammonia during their decomposition, like fish, flesh, \&c.

It is a curious fact, that those crops which at harvest time contain the greatest amount of nitrogen, like peas, beans, clover, \&c. are also those which receive least benefit from its application; while those containing less (like wheat, for instance) receive greater benefit from its use. The function of nitrogen seems rather to yield force, or to stimulate growth, than to supply plant food.

Second, our soils lack potash in an available form. New England soils generally contain enough, but it is there as a silicate, in a combination so nearly insoluble that it is virtually locked up. It is liberated thence only by slow degrees; by freezing and thawing, air and rain, especially by rain water, containing, as it does, a little carbonic acid.*

The third want is phosphoric acid. All soils capable of producing crops contain more or less of this, but nearly all in so scanty measure that it is more frequently needed than any other ash constituent of plants; and when present in insufficient quantity, plants make a feeble growth, are liable to many casualties which

* Late investigations have shown that potash is liberated from its insoluble connections by the agency of acid phosphate of lime, and to this fact, probably, is due a considerable degree of the surprising efficacy of a genuine Super Phosphate in not a fer instances. 
healthy and vigorous plants escape, and cattle fed upon the herbage of such land are subject to what is known as "bone disease."

These three substances, Potash, Nitrogen, and Phosphoric acid, are the most important and the most expensive which the farmer has need to buy; and all commercial fertilizers sold, whatever the name they bear, be it ground bone, guanos, of whatever name or kind, phosphates, or super-phosphates, or "perfect manures," or whatever else, which are really worth more than half a cent per pound, owe their value mainly to the presence of one or more of these substances.

An interesting question relative to means of fertilization is, whether it be the better policy for the farmer to buy manures directly or indirectly; that is to say, whether to buy commercial fertilizers, or commercial articles of cattle food, to be converted partly into meat or dairy products, and partly into manure. It is too broad a subject for discussion here, but it deserves more consideration than it receives. The true answer I believe would vary with circumstances, sometimes one and sometimes the other, and it should be the business of each farmer to ascertain which would be best for him.

The term "Commercial Manures" may be understood as embracing all those manurial substances which are usually purchased by the farmer, in distinction from those usually obtained from his own resources.

I do not propose to treat of them all in detail, but only to touch briefly upon the leading features of the more prominent among them; - and the first I will mention is Lime.

On some soils lime is useless or eren injurious, but on others it may be used to great advantage, and it might be profitably used to far greater extent than it is.

It has happened with lime as it has with many other things in this world of oufs; after having been extolled above their merit, they sink in estimation as far below their true value. The truth is, that lime is a special manure, and by no means a general one. 
Some things it can do with great advantage, and others it cannot do, but if attempted, perhaps harm instead. To a very limited extent lime may be usefully applied to furnish plant food-but ordinarily, soils contain enough for this purpose.

The chief office of lime seems to be that of an alterative. When applied to stiff clays, and to some soils neither clayey nor stiff, but rather mossy and wet and indolent; in a condition resembling, as near as anything, the chronic shiftlessness of some people we occasionally meet;-upon all such soils lime frequently causes highly beneficial changes, partly chemical, and these only partially understood; partly mechanical, but certainly beneficial; thus stiff clays are rendered more friable, and wet lands are made drier, as well as unproductive lands more fertile. Increase of fertility, by means of the use of lime, is probably as often due to its action in liberating potash from its insoluble combination with silica in the soil, as to any other effect of its application.

Lime is also usefully employed as an ingredent in composts of peat and muck, since it promotes the decay of vegetable fibre, and the destruction of certain harmful compounds of iron not unfrequently met with in mucky deposits.

The next I mention, is Gypsum;-Plaster of Paris,-or, as the chemists call it, Sulphate of Lime. On some soils this is a very efficient manure and the cheapest to be had. On other soils it is useless, and its price, whatever that may be, is thrown away. How it operates, - whether by furnishing plant food directly, or indirectly, or in whatever way inducing fertilizing results, nobody fully knows. There are plenty of guesses about its mode of operation, and some actual knowledge, but I am not aware that the numerous researches directed to this point, have resulted in satisfactory conclusions. If you would know-each for yourself-whether it will pay for you to use it-my advice is, that you submit the question to the only party who will give you an answer to be depended upon,- -and I pledge my word that you will not be charged an extravagant fee for the opinion. Lay the case before 
your own soils, and your own crops. Put some gypsum on your land and then put on the crops, and in autumn listen for the answer. You need not use much;-half a dozen quarts, on as many different square rods, in various parts of your farm, will give as distinct replies, as would the same number of tons on as many ten acre lots.

There are wide breadths of land where gypsum will cause an abundant growth of clover; - and with clover you can so manure land as to produce good crops of corn, or wheat, or grass. If you have such land, be sure not to stint the application of gypsum and clover seed.

Bones. The value of these depend largely on the phosphoric acid they contain, and which amounts on an average to twentythree per cent., or nearly a fourth part of their weight. It exists mostly in combination with lime, (as tribasic phosphate), a very little also with magnesia. Besides this earthy phosphate, bones have animal matter containing nitrogen, enough to yield five to six per cent. of their weight of ammonia upon decomposition. Bones, for the most part, are very tough, and require powerful machinery to reduce them to fineness. This is necessary if we desire early returns from their application, for a bit of hard bone weighing a quarter of an ounce will last ten or twenty years in the soil, before being fully decayed.

The phosphate in bones is of the kind usually called insoluble (i. e. tribasic), but it exists in particles so very minute as to be invisible, singly, to the naked eye. These are glued each to its neighbors by the animal matter. As the animal matter deciys in the ground the molecules of phosphate fall apart, and so extremely fine are they as to be slowly yet sufficiently soluble. Hence it is, that bone dust can often be used to advantage without being first treated with acid.

Some farmers are beyond reach of a bone mill. Such may, if they will, utilize bones in the following manner: Break them as small as possible, at odd jobs and leisure times; mix with un- 
leached ashes, and wet the mass. If possible, warm it also, which is easiest done by the heat of fermenting dung. The combined action of heat, moisture and caustic alkali causes the animal matter to give way, and the atoms of phosphate fall apmit in a state of such extreme division, as to be, for practical purposes, almost as useful as if made into superphosphate.

The difference between a bone manure thus prepared, and a "Siner Phosphate" (properly so called) is, that in the latter the phusphate is reudered "soluble" by a chemical change in its proportions, effected by means of acid; while in the former there is simply a physical subdivision effected by means of a chemical action which decomposes the cement which holds together the extremely minute molecules of phosphate in the bone. To give some idea of the extent of this subdivision let me say, that, were a eubic inch of bone divided into a million of little cubes, (each measuring the one-hundredth of an inch on either side) erery one of them would be more than a thousand times larger than the particles as they exist in bone. Now, because the degree of sulubility of substances difficult of solution is greatly enhanced by being made fine, you can readily see wlyy I stated that bone thus treated was nearly as useful as if made into superphosphate.

The next commercial fertilizer which I mention, is Peruvian guano. This, as formerly imported, contained from 15 to 17 per cent. of ammonia, but latterly from 11 to 13 per cent. The high price it bears is chiefly due to this content; for of all the manurial agents which the farmer has occasion to buy, the dearest is nitrogen in such form or combination that plants can appropriate it to their use. Peruvian guano contains a small percentage of potash; also about one half as much phosphate as raw bone; but as before remarked, its chief commercial value is due to its nitrogen.

Like other ammoniacal manures, its principal use is for grain and grass crops; and the chief profit from its use is realized upon lands rich in mineral constituents.

Peruvian guano cannot be continuously used and the crops sold 
off, without rapid impoverishment of the land, except upon soils rich in dormant mineral resources. A considerable portion of the land in the Southern States is of this character, and hence the high repute in which Peruvian guano continues to be held there.

But to use it with impunity in New England, it is imperatively necessary, that the bulk of all which is grown by it should be consumed upon the farm and returned to the soil in manure.

For general use among us, it is found that the proportions of ammonia and the phosphates in Perurian guano, are not those which may be employed to advantage. There is too much of the former in proportion to the amount of the latter.

It is found that a manure containing more phosphate and less ammonia is safer, and better to use, and cheaper to buy; and this experience, coupled with the fact that we have in fish guano, or porgy chum, so largely produced along our coast line, abundant supplies of a manure nearly identical in character and results, with Peruvian g’uano,- - has caused an almost total abandonment of its use in this section. It is true that our fish guano is of less uniform quality and less concentrated, but its cheapness makes amends for the difference.

It is much to be regretted that so large a proportion of the fish refuse is not better cured, so as to retain the manurial efficacy which it has while fresh. Within the last ten years, however, there has been a vast improvement in this respect, and yet there is need of a great deal more. When well dried immediately upon coming fiom the press, fish guano may be deemed to be one-half as valuable as Peruvian guano; otherwise one-third to one-tenth.

I come now to the consideration of Super-Prosphates, of which probably a larger amount is used in New England than of any other concentrated manure.

What is commercially known as a "Super-phosphate," is a concentrated compost manure, containing a considerable proportion of suluble phosphoric acid, together with a portion more or less insoluble, and usually a quantity of nitrogenous matter or of ammoniacal salts. 
It ought to contain as large a proportion of phosphoric acid in a condition available to plants, as it can be made to contain and yet be sold at a price admitting its profitable use in agriculture. It is not expected to be a chemically pure soluble phosphate, for this would place its cost far beyoud the possibility of economical use. Go to a chemist and incuire the price of potash. You can find it good enough for surgical use for about one dollar per pound, but for chemically pure the charge will be much higher. It is elear that no one will buy at such prices to put on land, or to make soap with, when he can obtain the same quantity in commercial potash, mingled with some impurities, but good enough for the use required, for a dime or two.

So too, if he asks the price of the purest phosphoric acid in the market, he will find it about three dollars per pound, but he can buy the same quantity in several pounds of a good superphosphate for a quarter of one dollar, and possibly for rather less.

To be commercially pure, a superphosphate should be made with skill, from good materials, and with no additions made to cheapen its cost, thereby reducing its quality.

To be entitled a really good article, it should contain not less than thirty per cent. of phosphates, and about one half this amount in a condition to be dissolved at once, and the other half as fast as it may be required by the plants. Such an article manufactured on a large scale can be afforded at the present time for about three cents per pound, at wholesale. At this price, and also with the additional cost of a pretty long transportation, it will, in a great majority of cases, where judiciously used, pay a large profit, both in increased quantity, better quality, and earlier maturity of the crops grown.

The aim of the manufacturer ought to be, to give the largest amount possible of fertilizing constituents, in the best relative proportions to each other, at the smallest cost. Whether all do so is quite another matter.

Let me here offer a word regarding the chemistry of the manu- 
facture of superphosphates. What is commonly called phosphate of lime-or as chemists term it, tribasic phosphate of lime, or more recently, tricalcic phosphate,-is a combination of three equivajeritis of lime with one of phosphoric acid, hence the name "tribasic,"-three of base with one of acid. This is the form in which it commonly occurs in nature. It dissolves in water very slowly and with difficulty, and hence is called insoluble. To convert this into soluble phosphate, or as known to chemists, monophosphate of lime, or monocalcic phosphate, it is needful to take array from tribasic phosphate two of its three equivalents of base, (that is to say, of lime,) leaving one of lime in combination with one of phosphoric acid. Combined in this proportion it is very easily soluble. Indeed, if made dry, by artificial means, it has such an attraction for water that it will take it from the air and become wet again. This change from a tribasic to a monobasic phusphate, or from insoluble to soluble, is effected by the agency of silphuric acid, which has a stronger affinity for lime than phosphoric acid has, and so the sulphuric acid takes away lime and combines with it, forming sulphate of lime, which is the same thing as gypsum. We do not put sulphuric acid.with tricalcic phosphate for the sake of making gypsum. By no means; for we can get enough of this ready made from sources in nature cheaper than we can make it. . But we do it for the sake of the other result, viz., the conversion of insoluble phosphate to soluble.

Thus you see that when only pure tricalcic phosphate and sulphuric acid are put together you have a mixed result, a compost, consisting of soluble phosphate of lime and sulphate of lime. Still more is the product a compost if bone is used in place of phosphate of lime alone; for ouly half of bone is phosphate-the rest being chicfly animal matter. This animal matter, while decomposing in the soil, yields ammonia from the nitrogen it contains, and this is as far as possible from being an objection, for we find that a superphosphate, the value of which consists solely in its phosphoric acid, is only a special manure, and fitted for certain 
crops, as turnips, peas, clover, \&c., and for soils particularly destitute of this substance. But let it contain also a fair proportion of ammonia, or of nitrogen in any form useful to plants, and it is adapted to many crops-Indian corn, grains generally, and vegetables generally, and to a great majority of soils. In other words, it is no longer a special but more nearly a general manure. You sce also, that the term "Superphosphate" is a commercial and not a chemical term. Formerly chemists used the term superphosphate to indicate the salt now known as monophosphate, but it is obsolete at present and only retained in commerce. It is equally shown that a superphosphate is, and necessarily must be, a compost, and one the value of which depends wholly upon the skill and fidelity with which suitable materials are combined in suitable proportions.

Many commercial manures sold under other names are simply superphosphates, such as "Ammoniated Guano," "Soluble Pacific Guano," "Phospho Guano," and many others. The change of title is probably due to the odium attached to the word superphosphate in the minds of many, and this in its turn is due to the vast amounts of trash which have been palmed off for Superphosphate.

The first general remark offered regarding the use of commercial manures is, that I would never recommend their substitution in place of farm-yard manures, nor in place of any manurial resources which can be procured at home.

The first business of every farmer should be to secure ways and means to preserve fully all the excreta of his cattle, liquid and solid; - -and I would here remark, that the liquid portions are rarely sufficiently thought of. For, where some kinds of food are employed, as clover hay for example, or cotton-seed cake, the value of the liquid far exceeds that of the solid portions.

I would have him by the employment of dry earth, daily applied, preserve fully the manurial value of the excreta of his family;and this is a resource, the importance of which to the farmer is vastly greater than is commonly supposed. There are whole 
nations of the most successful agriculturists on the face of the earth, who depend almost wholly upon this alone. We may well profit by their example in economy; and in doing so, reap a double advantage,-not only make large gains, but avoid a too frequent nuisance. In a word, I would have every home resource laid under contribution and taxed to its utmost, (within the limits of economy) before he turned to any outside resources whatever.

I said I would never recommend the substitution of commercial fertilizers in place of the home supply. I would no more do so than I would recommend the substitution of commercial illuminators in place of sunlight,- - and I would not do this for two reasons; first, the sunlight is better, and, second, it is cheaper. Nevertheless, there are times and places where sunlight is not to be had, and people who pay money for commercial illuminators usually believe that they get their money's worth, and this, too, in spite of frand, which manifests itself in the fact that gas sometimes lacks illuminating power, and is sometimes loaded with noxious vapors, offensive to the senses and deleterious to health; and in spite too, of the fact that petroleum oils occasionally explode in the hands of those who use them and burn deeper than barely to make a hole through their pockets.

Notwithstanding all the drawbacks which exist to the use of commercial illuminators, they are extensively used. Their manufacture is a respectable business, and for aught I know, a lucrative business. On the whole, taking all their merits and demerits into consideration, they who buy and use are content to buy and use again; and I venture to predict that this will continue to be the case for a long time to come.

It is not to be denied that there has been, and is still, a great deal of cheating in connection with the manufacture and sale of commercial fertilizers. It is a busioess which furnishes great facilities for fraud, and dishonest men take advantage of then. This is chiefly due to the fact that the color, smell and general appearance of the article sold furnish no trustworthy indication of 
its real value. This can only be determined by a careful and somewhat costly chemical analysis, or by full trial in the field, upon various soils and crops and in different seasons. But there is nothing to prevent honest and capable men from manufacturing and selling a good article at a fair price.

The question is so frequently asked, what security can we hare against fraud? that I may be allowed to offer a few hints. The popular demand, if judged by the echoes of the agricultural press, is for "a rigid system of inspection," under a law to be enacted for the purpose. The fatal objection to this is, that insuperable practical difficulties lie in the way of its execution. It would be a very different matter to inspect concentrated manures from inspecting beef and pork, or fish and flour. For these and the like, a careful examination by trained senses would suffice; but neither sight, touch, taste or smell afford any criterion of the value of a manure. If these are to be the tests, it is easy to make the worst appear as well as the best.

In the case of manures, analysis is indispensable; and this requires days of time, and some outlay for chemicals and apparatus for every sample. Unless the inspector stood by during the whole process of manufacturing and packing, every package must be inspected separately, and the cost would exceed that of the manure itself. And then how could grades enough be fixed to distinguish between the various shades of quality, from the worst to the best?

Even analysis itself, valuable and indispensable as it is, does not supply all the information desirable. At least no ordinary analysis, requiring not more than a week of time, or costing not more than twenty-five dollars, can furnish full data for an estimate of value; and between different manures must sometimes fail to give corructly comparative values.

This may be best shown by illustration. Suppose a chemist should take the superphosphate made by the Cumberland Bone Company, near Portland, (and I mention this because it is the only 
commercial fertilizer, so far as I know, which is made as that is) he could readily determine the amount and proportion which it contains of soluble and of insoluble phosphoric acid, and of ammonia, and also whether the latter be ready formed or is yet to be formed in the soil by changes to take place in nitrogenous matter contained in it, but he cannot so readily determine the source from whence that portion of phosphoric acid which he calls insoluble is derived, nor can he readily determine the degree of ease with which plants could appropriate it to their use. The chemist terms a portion insoluble because it does not dissolve at once in pure water, which is the solvent he employs for this purpose; yet if its presence is due to pure, finely ground, raw bone, used in its maunfacture, as it is in the article I have named, it is wholly available to the needs of the plants after being in the soil for a month or two, and fully as fast as they require it; for, although not soluble in pure water, it is gradually soluble in rain water, which always contains some carbonic acid.

Suppose now another superphosphate is submitted to his analysis which is made from a mineral or fossil phosphate, and which by his process shows the same constituents in the same quantities and proportions as the first. Most people would say at once, it must have the same value; and so it would so far as the soluble phosphoric acid is concerned, for this would act with the same promptness and efficiency whatever its source might be, but it would be very different with that portion which he calls insoluble. This is dissolved with ease in the powerful acids which the chemist employs, and so he knows it is there contained, and he sets down its fluntity with precision and accuracy, but it is no more soluble in rain water, nor of any more use to the plants than is the potash which is contained in many rocks.

We may pulverize feldspar, or granite, of which there are millions of tons all about us. Both contain potash in considerable quantity; but the ground rocks would not help plants grow as ashes would, and why? Because in one case it exists in a really 
insoluble condition and not arailable to the plants, while from wood ashes the plants can get it as fast as they need it. The difference in the effect of two such superphosphates as I have described, provided they contained not less than three or four per cent. of soluble phosphoric acid, might not be noticeable upon the crops during the first year, or at least not until near harvest time, but either at the harvest, or in the second and subsequent years, it would be very marked.

Take another illustration. Suppose a sample of pure, finely ground raw bone be sent to the chemist for analysis. He will report about 23 per cent. insoluble phosphoric acid in its earthy portion, and in its animal matter, nitrogen equal to about 5 per cent. of ammonia, and he says truly. Now let him analyse a mixture of ground apatite (mineral phosphate) and leather chips. IIe finds the same constituents as in the bone and in as large amounts; yet the latter will have about the same effect on crops as so much gravel, and would be about as worthless, while pure fine bone dust everywhere readily brings a price nearly equal to that of good superphosphate. The reason is simply this, that the bone, if fine enough, gives to the plants what they want, nearly as fast as they require it, while the phosphate of the mineral is insoluble in reality as well as nominally, and the leather, unlike most animal substances, resists decomposition and refuses to yield its nitrogen as ammonia. This is an extreme case, not likely to occur frequently, and cited to illustrate the point in hand; but in larger or less degree there is usually a difference between intrinsic value and that indicated by analyses made in the usual methods. But notwithstanding the imperfections of analysis, it is the only available method, and is abundantly sufficient to drive out the great bulk of trashy matters so persistently urged upon farmers.

In Great Britain the usual method has come to be, to buy by guarantied analysis. That is, you buy an article warranted to contain a stated amount of soluble and insoluble phosphate, ammo- 
nia, \&c., and if it fuils to give satisfaction, you cause a sample to be analyzed, and if it be found to contain less than the guarantied amount, recover damages of the vendor.

What I would like to see is, a law compelling every manufacturer to affix a label stating the contents of its more valuable constituents, with provisions for recovering a fixed and sufficient sum for every pound which might be found deficient therein.*

There is another method of obtaining a fair degree of security against fraud, which is to buy of honest manufacturers and dealers; and if you cannot be sure of finding such as possess true integrity of character, connected with sufficient intelligence, you can find those who have invested more of reputation and more of capital than they are willing to put in jeopardy by fraudulent dealings. Such men cannot afford to cheat. They have understanding enough to enable them to comprehend and act upon the low grade commercial truth contained in the adage that " Honesty is the best policy."

Another hint may be of service. When you see a quack nostrum, or anything else, extensively advertised, and pusited off by agents at large expense, does not the idea suggest itself, both that the article brings a large profit, and also that it so far lacks real merit as to need a special fertilizer in order to bring up continuous crops of customers? It is very well to advertise a new article sufficiently to bring it to notice, but after that it should find buyers on its merits, without excessive expenditure for either advertising or agents. It does not require much of that sort of eflort to sell St. Louis flour or Portland kerosene, or some other manufactures which might be named.

I am aware that it is very common to hear observations implying that frauds abound with commercial fertilizers, buyoud any other branch of trade. I doubt if this is the case. When you go to the

* Such a law was enacted at the session of 1869 by the Legislature of Maine, and will doubtless prove of great service. 
druggist to get powdered rhubarb, or ipecac, or a bottle of wine or brandy, for a sick member of your family, do you always get that which is pure? When you go to the grocers' for pepper, or ginger, or soap, or cream of tartar, do you never get anything but what you ask for? Is all which is sold for roasted, ground coffec quite innocent of peas and rye? When you buy a coat, does it never contain any more shoddy than is set down in the bill?

There is one single fact bearing on the proportion of frand to fair dealing, in the sale of commercial fertilizers, which comes to my mind with the force of mathematical demonstration. It is the steady and rapid growth of the manufacture and sale,-from nothing to great magnitude,- within a term of less than thirty years. It was about 1840 when Peruvian guano was first imported for agricultural uses. Very nearly at the same time the value of superphosphate, i. e. of a true soluble phosphate, was first recognized. The introduction of both was slow during the earlier years following, but latterly it has been more rapid. What amount is now sold annually I camnot state; but a few facts can be given bearing on the subject. In 1839, the first consignment of Peruvian guano arrived in England. It consisted of thirty bags. The first cargo arrived in England in 1811. About a dozen years later the sales amounted to upwards of $£ 1,000,000$ annually.

One of the most interesting papers relative to commercial fertilizers which has come to my notice, is a chapter devoted to the "Industry of lianures," in the Chemical Report of Dr. Hoffinan, of the International Exhibition held at the (Sydenham) Crystal Palace in 1864. It is there stated, that the amount of superphosphate mixed daily at the establishment of Mr. Lawes (one of the earliest manufacturers, as well as one of the most successful, and who deserves the gratitude of every farmer for his untiring labors and liberal expenditures in aid of progress in agriculture), was one hundred tons, and his yearly product was from eighteen thousand to twenty thousand tons; and he estimates the amount made at that time in England to be from one hundred and fifty thousand 
to two hundred thousand tons annually. A statement more recently made, and believed to be correct, is, that the present amount exceeds two hundred and fifty thousand tons annually.

The introduction of commercial manures into use in the United States was later and slower than in Great Britain, and their employment is chicfly limited to a moderate distance from the seaboard. Yet, it is believed that the annual consumption of superphosphate now reaches one hundred thousand tons yearly, and is both steadily and rapidly increasing.

Now consider that the trade in commercial manures has grown to its present magnitude under the palronage of farmers alone-that these large amounts are bought and used and paid for by a class of men who are habitually cautious about introducing new ways into their practice, averse to parting with money except for "value received," and are as capable as any other class of judging whether they get money's worth for money. I do not say that a farmer may not be cheated as easily as another man,-for once,-but to believe that farmers, as a class, for a series of years will continue to pay out money in sums larger and larger every year, for what does not give satisfaction, I can no more believe, than that five and five are equal to forty. Do not the facts rather prove, that so much as has been skilfully and honestly manufactured, must have been very good, and very profitable at the price it bore? How else, by any possibility, could the trade be sustained, and exhibit a steady growth under the accumulated odium of all the frauds connected with it?

Fraud is not the only reason why commercial manures sometimes fail to produce the results anticipated. Innorance has something to do with it. I have been witness to a degree of ignorance on the part of a manufacturer who advertises and puffs his wares loudly and persistently, which, if it had only been related to me I should have been slow to believe, except upon testin ony impossible to discredit. And there is more or less, not very unfrequently, of mismanagement in their application and use-and let me say here, 
that ample experience has shown that the best method of using either Peruvian guano, or superphosphate, or fish guano, is not to put the whole amount used in hills, as is most often done, but to compost two-thirds or three-fourths of what is to be applied with barryard manure, if any of this is also to be applied, and then to spread and harrow it in, applying only the remainder in the hills. If no other substance is to be applied to the land, then let the two thirds or three-fomrths be spread and harrowed in, and only enough pul in the thills to give a good start to the plants, and let this lillle be sprear in the hill, and not merely dropped in a small pile. It should be covered with a little eartli, also, as well as spread, to avoid injury to the tender germs. To expect tender rootlets to thrive by pushing into a small pile of concentrated manure, such as you desire to buy, is as reasonable as to expect a sucking child to thrive on a diet of beefsteak and brandy.

It appears to me that the general tenor of the American agricultural press is not altogether what it might be, nor that which is calculated to throw the truest light on the subject of commereial fertilizers. Instear of giving the results of clitical, impartial and thorough investigation, thereby imparting real instruction, we get more of simple reflection of current opinion. And the expression of that opinion comes mostly from those who are, from any cause, disappointed in their use. Successful instances are sometimes given; but the great mass of those contented with their purchases and resulls, are also contented to pocket their gains and to continue to buy without troubling editors or the public with narratives of their opinions or their operations.

We have, also, scattered through the columns of agricultural newspapers, a good deal of well meant, but I think injudicious advice addressed to farmers. I refer now chiefly to the advice, so common, for farmers to prepare their own superphosphate, in place of buying it. They direct the farmer to take a given amount of bone dust, and add so much oil of vitriol, and so much water, and perhaps, also, some other substances to "extend" it or to 
make it bulkier or drier. To show that this is injudicious advice, it will suffice to state a few facts. In the first place, the farmer must buy his bone dust. He cannot make it. With considerable labor he may break them up somewhat; but this will not suffice for this purpose. They should be made as fine as common sawdust; - and if he goes to buy, and can find such as is pure, he has to pay as much for it as if he bought it already made into superphosphate; and he will also be likely to learn that the adulleralion of bone dust is quite as great as that of superphosphate; clam shells, oyster shells, and the tumings of vegetable ivory, and other tuash being not unfrequently mixed with it. Then he must buy his oil of vitriol at retail, and pay more for it than the man who buys in large quantities, or who manufactures it for his own use. On the whole, he will find that, even counting out all imperfections in his product, arising from lack of practical skill, or chemical knowledge, and also any accidental loss or damage from breaking carboys, or spilling a powerfully corrosive liquid upon his clothes or his person, he is still worling as really at a disadvantage as if he attempted to do his own paper making by grinding rags to pulp, and working this into sheets by hand labor, as was done years ago; or by inducing his wife to spin and weave cotton for the sheets and shirts of the family, instead of exclanging his farm products for factory made goods.

Sufficient evidence of this is found in the fact that although farmers are sometimes induced to try the experiment for once, it is very rare for any to repeat it a second time. One dose of this sort of experience, (so far as iny observation has extended) suffeces for a cure in nineteen cases out of twenty.

If authority be wanted, I might quote from a lecture delivered in Bath, (England,) by the well known Prof. Voelcker. Ile said: "I do not recommend the system of home-made superphospliates. For some time we made our own at the Agrieultural College Farm at Cirencester; but taking the quantity of soluble phosphate produced, we found we could not make it so cheap as it could be 
bought. There is a decided advantage in buying superphosphate. All that was required was to take care that what they bought was a good sample. It is a manure which can be produced at a cost rarying from $£ 5$ to $£ 12$ per ton. (That is, from $\$ 25$ to $\$ 60$ per ton, gold.) It was desirable, therefore, that the farmer got the full value for his money." Again, in the same lecture, Dr. Voelcker says: "I lay particular stress on the term intelligent manufacturer, becanse I believe it to be a hazardous undertaling for the farmer to prepare his own superphosphate, considerable knowlerlge being required, together with practical acquaintance with the method, and proper appliances."

There is some editorial advice bestowed upon farmers to which I know not what epithet to apply. It seems impossible to charge it to ignorance, or to a willingness to deceive;-judicious, we cannot call it, injudicious, is not sufficiently descriptive. Let me read you a sample of what is now referred to. It is from "The Buston Jommal of Chemistry," "Devoted to Chemistry as applied to Medieine, Agriculture and the Arts. Edited by Jas. R. Nichols, MI. D." The number for April 1, 1868. It appears in the editorial column, in leaded type, and with every appearance of being from the pen of the editor. It reads as follows:

"Supetrnosphates. - Several of our agricultural friends have written to us, asking which kind of "superphosphate" we would recommend them to purchase. Certainly there ought to be only one kind of superpbosphate, and that a genuine superplsosplate of lime, containing at least ten per cent. of soluble phosphoric acid, and an equal quantity of insoluble, in addition to the phosphate of lime. We do not knorv of any brand we can recommend as being properly manufactured, genuine superphosphate of lime. If there is any in the market, we have not been able to find it, and we have scarched diligently. As the inquiries are presented, we can make no answer. If the qucstions should assume another form-" What compounds, composts, or mixtures, such as are put up in barrels, and labelled 'superphosphate,' we would recommend," we should still be unable to reply; as we have found these mixtures to vary so exceedingly in fertilizing value, little reliance can bo placed upon them. In color, some are quite dark; others gray, or light yellow. In odor, one is like fish offal, another like currion; others have a kind of sulphurous smell. The color is due to an admixture of charcoal, or bone-coal, or sugar refiners' waste, in varying quantitics. As regards the origin of 
the differing odors, we suppose, when the manufacturers run short of cheap fish pomace, they substitute dead cats and dogs, or other decomposing flesh. As a rule, that "superphosphate" which has the darkest color and the most abominable smell, sells the best, as it is regarded the "strongest." Manufacturers understand this, and take advantage of it. True, genuine "superphosphate" is almost colorless, and has but a faint acid smell, not in the least unpleasant. To manufacture such, all that is required is to dissolve fine bone-dust in oil of vitriol, 150 pounds of the former to 80 of the latter, with the addition of sufficient water to form an intimate and perfect mixture. In the home manufacture of this fertilizer, 60 pounds of acid, with 150 of fine bone may be employed, as it is better to avoid the risk of any free acid remaining in the mixture after the action is over. We have given, in a former number of the Journal, full directions for making superphosphate upon the farm. Farmers ean and should make their own superphosphate."

I have not the honor of a personal acquaintance with the writer of this article, but it is due to say, that Dr. Nichols is understood to enjoy the reputation of being a very estimable gentleman, a practical and scientific chemist, and farmer also, and occupies a position at the head of an establishment for the manufacture and sale of chemical preparations, chiefly medicinal. It is also proper to say that the Journal in question has been the vehicle of much information and advice which was accurate, sensible, and eflective for good.

I quote this editorial partly because it utters no uncertain sound, partly because its authorship secures its acceptance by many who would scrutinize as loud a statement if made by one possessing less reputation as both a chemist and an agriculturist, but chiefly because, appearing in a journal claiming twenty-five thousand readers, and having been extensively copied into agricultural and other newspapers, it obtained a rery wide circulation. Copies were sent me last spring from various parties, with the inquiry what answer I had to make. But I replied to none. I had enough else to do, and part of it was connected with the manufacture of a respectable superphosphate. I felt some as Nehemiah did, when invited to come down from the wall he was building, and hold a conference on the subject. He felt that the wall was worth more than talk about walls; and I thought the 
making of a good superphosphate was the best answer to the article. You can judge, mearly enough, what reply I would deem appropriate to most of its allegations, but I will remark in relation to the diligence of search for a good superphosphate, said to have been madê, that I can conceive of no obstacle which need prevent one possessing ordinary locomotire powers, in the usual condition of the streets of Buston, in less thau teu minutes' walk from the office of the Jummal of Chemistry, from reaching sereral places where a ton or a hundred tons of good quality could be had at a fair price.

It seems strange, too, that it never occurred to the Doctor that the "strong odor" might possibly have had another origin than from "dead cats and dogs." In one superphospliate extensively sold, a strong, garlicky smell is due to the addition of ammoniacal products obtained from the destructive distillation of bones in the manufixcture of bone charcoal; and an effective addition it is, rendering it more stimulating to vegetation. In the superphosphate of the Cumberland Bone Company is an addition made for the purpose of rendering it repellant to vermin in the soil infesting plants, like wire-worms, onion maggots, etc. But the chemistry of the article quoted, and its arithmetic, are farly open to criticism. The writer says that "there ought to be only one kind of superphosphate, and that a genuine superphosphate of lime, containing at least ten per cent. soluble phosphoric acid, and an equal quantity of insoluble addition to the phosphate of lime."

T'eu per cent. soluble and an equal quantity of insoluble make twenty per cent. Bear this in mind, and then note that lower down he tell us how to make just this same "genuine superphosphate." Ile says "To manufacture such all that is required is to dissolve fine bone dust in oil of vitriol-one hundred and fifty pounds of the former to eighty pounds of the latter ;" (with the addition of water, \&c., but as the water mostly dries out again, though some is retained in combination, we will not count that in). The product of superphosphate weighs one hundred and fifty pounds, (for the bone) plus 
eighty pounds acid, making two hundred and thirty pounds at the least. Now, bones contain one half their weight of phosphate, (if the bone be old and hard a trifle more; if young and soft rather less; fifty per cent. is a full estimate and more than the Doctor himself puts it in another place.) Of this phosphate less than half is phosphoric acid,* (about forty-six per cent.) so that, as near as may be, aroiding small fractions, bones contain twenty-three per cent. of their weight of phosphoric acid (as I stated a little while ago). Now, if one hundred pounds of bone contain twenty-three pounds of phosphoric acid, one hundred and fifty pounds contain thirty-four and a half pounds. If two hundred and thirty pounds superphosphate contain thirty-four and a half pounds phosphoric acid, what per cent. is that? If my answer is right, it is just fifteen per cent.,-yet he tell us "containing at least" twenty per cent. Here is a serious falling off, but the astonishing part remains. II tells us "containing at least ten per cent. soluble phosphoric acid, and an equal quantity of insoluble, in addition to the phospleate of lime." Why! every particle of the phosphate in bones, whether phosphate of lime or the trifle of phosphate of magnesia, has been used up to furnish fifteen per cent! There is not an atom of phosphoric acid in bone except in its phosphates, and yet he tells us twenty per cent. phosphoric acid in addition to the phosphate of lime!

All I have to say about this is, that if the facts are as he states, the case more than equals a realization of the desire of the boy who wanted to "keep his pie and eat it too"-for here the pie, weighing only fifteen ounces before it is eaten, weighs twenty ounces "at least" after it is eaten. Ought such advice to be termed judicious-or injudicious-or what? $\uparrow$

* Known in the new nomenclature of chemistry as phosphoric anhydride or phosphoric oxide ( $\left(\begin{array}{lll}\mathrm{P} & 0 & 5\end{array}\right)$

+ Dr. Nichols seems to have been unfortunate in his arithnetical statements in connection with commereial manures on other oceasions; one instance of which may be named here. In a lecture before the Massachusetts Board of Agriculture, given in Flint's 
Permit me now to read a brief extract from a recent British periodical. It reads as follows: "The development of the artificial manure trade has been most remarkable; and, whilst ummistakably advantageous from one point of view, we are led to question whether the ficility with which we have been sulplied has not led us to be careless about our own resources. The rery materials for which we pay so heavily are too often permitted to ooze away into the nearest ditch and pollute our streams. Baron Liebig, to whom in great degree we owe our present kmowlelge, denounces this terible waste, and warns us that the time will come when our reckless extravagance will bring down on us hravy discomfort; and that the decay of our great country will date from the day when our supplies of phosphates fall short. Without going quite so far, we would earnestly impress our ereaders with the importance of taking care of the manure of the farm. It is sad to see the ignorance that is apparent in unsponted yards, washed out manures, and the porter-colored horsepond. Even if it could be proved that the waste thus incurred can be more economically made up by the purchase of artificials than by the oulay necessary to prevent it, it would still be clear that, taking a comprehensive view, and duly considering the future, our practice is most reprehensible."

Here too are words of warning, and words of advice, but a new front is presented; the burden is changed; the words have another ring to them. Now, the trouble is, that commercial manures are so good and so cheap, that the imminent danger is, of forgetting the farm-yard; and the appeal is, not to permit the pros-

Report for 1866-7, page 237, we read as follows: "A direct estimation of the nitrogen gave in 1000 pounds of bones, 50 pounds. ***** Hence we find they afford about 20 per cent. of nitrogen in their fresh condition." The error here; in calling a twontieth part, 20 per cent, instead of 5 per cent;, is so gross and palpable that any careful reader would readily detect it ; and it would pass for a slip of the pen, were it not that, in a book published not long subsequently, entitled "Chemistry of the Farm and the Sea," consisting chiefly of previously written papers, newly arranged and revised, we find the same error repeated in the same words. 
pect of present gains to induce forgetfulness of the future, and of the needs of posterity. He talks in the strain a wise man would have used with the settlers in Aroostook fifteen or twenty years ago, or in Western New York at an early day, when he saw them carting manures to the nearest stream, merely to be rid of them.

Let me say here, that the trade in commercial manures seems to be passing through the same phases which it undervent in Great Britain a few years earlier. About 1855, Dr. Voelcker made the following statement: "If ever there was a time when the agriculturist had need to exercise special caution in the purchase of artificial manures that time is the present, for the practice of adulterating standard fertilizers, such as superphosphate, gruano, \&c., has reached an alarming extent. *** it is but right, however, to mention that it is far from us to censure indiscriminately the whole class of manufacturers and dealers; for we know many highly respectable, fair dealing and skilled parties who well deserve the support and encouragement of the agriculturist, and who are as anxious as every right minded person to put a stop to the scandalous proceedings now and then revealed to us."

Recently, he says in his annual report as chemist to the Royal A gricultural Society, "The number of analyses made for meinbers in 1868 is four hundred and thirty-two, a larger number than in any previous year. By far the larger proportion of the class to which superphosphate belongs were fouml of good quality, well prepared and worth the money at which they were offered for sale. Of late years the manufacture of superphosphate has much improved, and notwithstanding its superior quality and intrinsic value the marketprice has not been increased."

It would seem, therefore, that the manufacture and sale has for the larger part, passed into the hands of "highly respectable, fair dealing and skilled parties;" and no doubt can be entertained that a similar result will be reached in this country, and with sreater rapidity than obtained in England.

The remark is frequently made, "I don't beliere that any com- 
mercial fertilizers are as good as barn manure, and therefore I will have nothing to do with them." To such my reply is, that the premise is admitted without the slightest hesitation, but the legitimacy of the conclusion is open to doubt. If you have farmyard manure enough, you are the very man to let commercial manures alone. But have you?

Suppose I was to visit the shop) of a surgeon-mechanic, and after critically examining the artificial legs and arms and crutches and spliuts and supporters, should tell him that I thought his wares were vastly inferior to those of nature's providing, and that I would have none of them; I submit whether he would not answer my objection fairly, and fully, by replying,_- " I do not expect you to buy of me. I labor not for the whole, but for the crippled. There are those who are willing to avail themselves of my assistance, and to pay me for my labor."

So it is with most of us. There are few New England farmers who do not have to deal wilh crippled land-land unable to bear the burdens of a successful agriculture without artificial helps-unable, too, in part, because we, and our fathers before us, have dealt hardly by it. We have taken too much from it, and have given too little to it; and the day of reckoning has come, as come it always will, in every case, sooner or later, where the laws of order are violated. It is well for us to remember that God's laws all lake care of themselves, in due time, and equally so whether the laws be about theft and adultery and idolatry, or about gravitation and nutrition and fertilization; and they require neither detective police, nor judge, nor jury, nor sheriff; they execute themselvesnobody dodges one of them. The man is to be pitied who confounds His laws with statute enactments manufactured by legislatures.

It is our duty, and our privilege to repent, to try to make good the evil of our misdeeds in the past, and thus to leave our lands to our children better, and not worse, than we found them. And this brings me to the consideration of a very important point in the use of commercial fertilizers, and one which is too often over- 
looked, which is this: We all know that crutches are used with various intent. By the hopelessly lame they are used for temporary relief only; but by those not incurably crippled, they are used with the purpose of getting well,-they are used in a way calculated to accomplish the end in view, in such a way as may enable to lay by strength, so as, by-and-by, to do without antificial helps.

Such should be our intent also. Our lands are not hopelessly crippled. If we can but add manure enough for a limited term, to enable us to get good crops, and then use those crops in a r.ty whith shall enable us to return to the land the means of future fertitization which the'y are capable of yielding, then we may retain and sustitin the degree of fertility which we obtained by temporary artilieial aids.

We hear it often said, that special manures tend to exhaust land. I tell you manures never exhaust land. It is the crops, which the manures enable you to take from the soil, which exhaust it. If we sell these off from the farm, retuming nothing in their places, the land is, sure enough, in a fair way to run down; and the more it produces, after this fashion, the faster it will run down. But if we will deal honestly with it, first converting the crops into meat and milk and wool, and manure, and then save the manure and apply it, thus returning a fair proportion of what we have taken from the soil, we may have, for our own use, or to sell, all which has been contributed to the crops from the atmosphere and from the dews and rains of heaven, and besides this, a portion also of the ash constituents of the plants grown, these being annually liberated from the hidden, dormant resources of the soil, through the agencies of nature and of cultivation. And this will suffice to support us handsomely, and such practice can be kept up, with increasing ferlitity, as long as the world stands. 









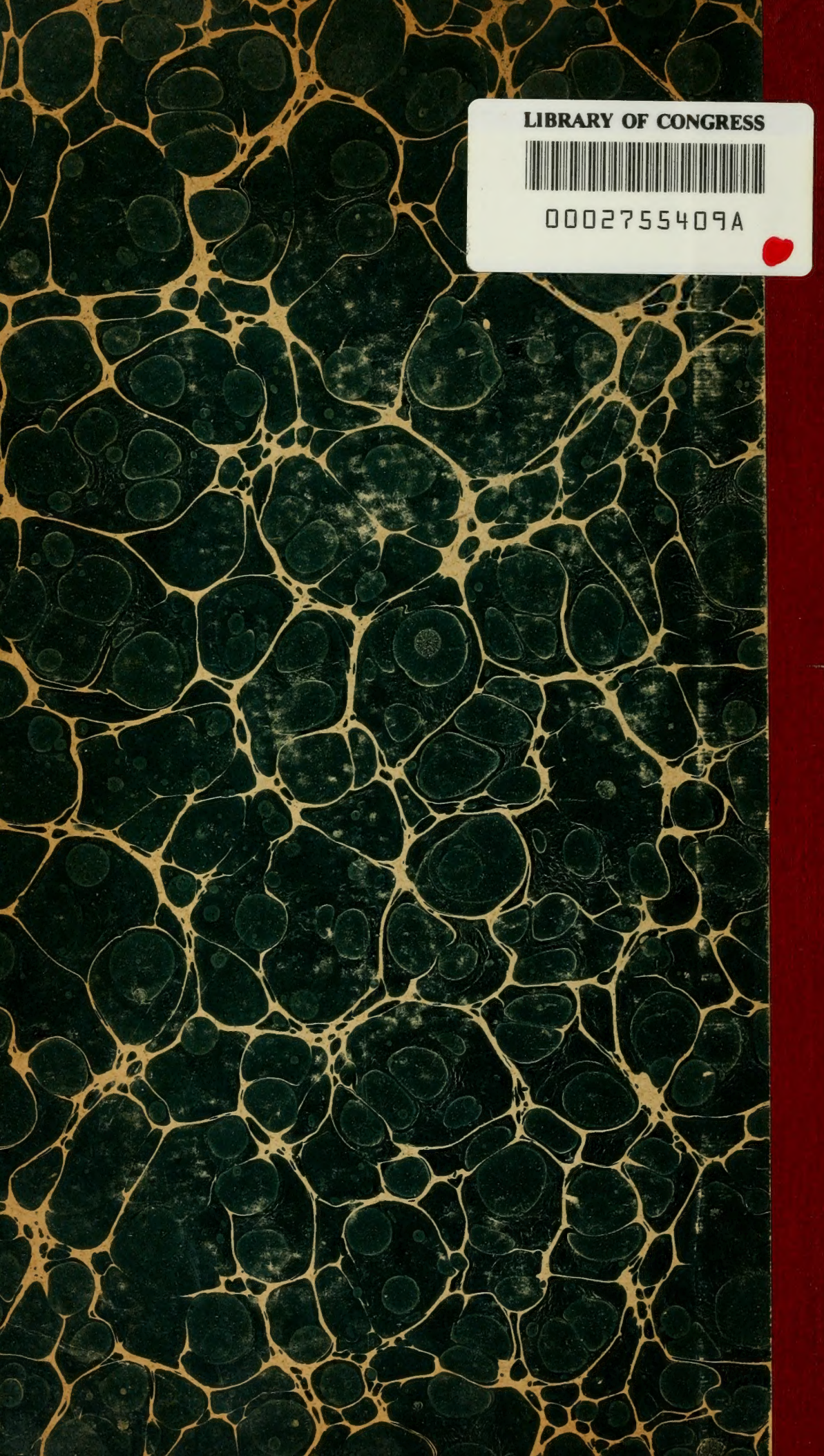

